\title{
KOMODIFIKASI MISTIS DALAM PROGRAM REALITY SHOW PENCARIAN JODOH GARIS TANGAN DI ANTV
}

\author{
Muthmainnah $^{1 *}$, Mulharnetti Syas ${ }^{2}$ \\ ${ }^{1}$ Jl.Pagujaten Timur Rt 07 Rw 007 No.03 Ps. Minggu Jakarta Selatan \\ ${ }^{2}$ Program Studi Ilmu Komunikasi, Fakultas Ilmu Komunikasi Institut Ilmu Sosial dan Ilmu Politik Jakarta \\ *Penulis korespondensi; Email: 'inahmuthma@yahoo.com; ${ }^{2}$ mulharnetti@yahoo.com
}

\begin{abstract}
ABSTRAK
Penelitian ini mengkaji makna mistis dan praktik komodifikasi yang disajikan pada program reality show pencarian jodoh Garis Tangan di ANTV. Penelitian ini menggunakan metode analisis semiotika model Roland Barthes dengan pendekatan kualitatif. Pada hasil analisis makna denotasi pada program tersebut, yaitu penggambaran ritual-ritual mistis yang dilakukan oleh kedua expertise yaitu Arbi dan Rudy dalam usaha mereka untuk menjodohkan antara kandidat pria dan wanita. Makna konotasinya adalah ritual-ritual yang dilakukan seperti membaca garis tangan, merasakan aura, dan menghipnotis atau melakukan relaksasi terhadap peserta pencarian jodoh. Sedangkan mitos yang disajikan adalah kepercayaan-kepercayaan mengenai adanya makhluk gaib yang dapat memberikan bantuan terhadap manusia melalui perantara orang pintar (dukun). Masyarakat membutuhkan hiburan mistis untuk menjawab rasa ingin tahu mereka terhadap misteri fisika (mistis). Karena, bagi mereka, itu merupakan sebuah petualangan batin. Hal semacam itu yang mendorong manusia untuk menyukai tayangan-tayangan mistis. ANTV memanfaatkan kebutuhan masyarakat terhadap hiburan mistis sebagai sebuah komoditas, dimana mereka memasukkan unsur mistis dalam program reality show pencarian jodoh "Garis Tangan" sejalan dengan selera pasar yang akan menarik minat penonton dan menaikkan rating.
\end{abstract}

Kata kunci: Komodifikasi Mistis, Reality Show Garis Tangan, Semiotika Roland Barthes.

\begin{abstract}
This research examines the mystical meanings and practices of commodification presented in the ANTV reality show matchmaking program. This study uses the semiotic analysis method of Roland Barthes' model with a qualitative approach. In the analysis of the meaning of denotation in the program, namely the depiction of mystical rituals carried out by the two expertise, namely Arbi and Rudy, in their efforts to match male and female candidates. The meaning of the connotation is rituals that are carried out such as reading the palm of the hand, feeling the aura, and hypnotizing or relaxing the matchmaking participants. While the myths presented are beliefs about the existence of supernatural beings who can provide assistance to humans through intermediaries of smart people (shamans). The people's need for mystical entertainment is an inner adventure to answer their curiosity about the mystery of physics (mystical). Things like that that encourage people to like mystical shows. ANTV takes advantage of the public's need for mystical entertainment as a commodity, where they include mystical elements in the matchmaking reality program "Lines of the Hand" according to market tastes that can attract viewers and raise ratings.
\end{abstract}

Keywords: Mystical Commodification, Garis Tangan Reality Show, Roland Barthes Semiotics.

\section{PENDAHULUAN}

Televisi dipandang memiliki beberapa pengaruh besar, Novak mengatakan: "Televisi adalah pembentuk geografi jiwa" (Vivian, 2008:225). Sebagian orang dewasa, banyak yang sudah terbentuk jiwanya melalui informasi atau budaya yang dibentuk oleh televisi. Di Indonesia, televisi memiliki berbagai macam program acara. Namun, lembaga penyiaran lebih didominasi oleh tayangan gosip dalam bentuk infotainment, sinetron dan reality show (Wahyono, 2011:91).

Reality show adalah program yang isi tayangannya menggambarkan tentang realitas sosial kehidupan masyarakat. Saat ini, program televisi bergenre reality show menjadi sangat popular di layar kaca Indonesia.
Salah satu program reality show adalah program "Garis Tangan" di ANTV. Garis Tangan di ANTV merupakan program reality show yang memadukan pencarian jodoh dengan mistis. Program yang dipandu oleh Uya Kuya ini tayang setiap Jumat, Sabtu, dan Minggu pukul 22.00 WIB. Sebanyak 31 peserta perempuan dan 31 peserta laki-laki yang sudah terpilih melalui audisi akan terlibat dalam program ini. Pencarian jodoh dilakukan dengan cara mengungkap sisi lain masa lalu dari calon pasangan dengan bantuan dua expertise yang merupakan seorang indogo atau orang-orang berkemampuan khusus. Uya Kuya dan para expertise juga melihat apakah mereka memiliki kecocokan satu sama lain atau tidak dengan melihat latar belakang masingmasing peserta. 
Program televisi dengan muatan mistis sebenarnya sudah diatur dalam pedoman perilaku penyiaran standar program siaran (P3 dan SPS) Bab 16 pasal 30. Pasal tersebut berisi tentang pelarangan dan pembatasan program siaran bermuatan mistis, horor, dan supranatural. Namun kenyataanya masih banyak pelanggaran yang dilakukan oleh televisi dalam mengemas program siaran dengan memasukkan unsur mistis. Hal ini dapat dilihat dari banyaknya aduan kepada Komisi Penyiaran Indonesia (KPI).

Selain melanggar aturan siaran yang sudah ditetapkan, televisi juga kerap memainkan strategi "profit oriented" yang dilakukan dengan cara mengkomodifikasi segala bentuk tayangan (Ishad, 2014:53). Saat ini televisi bukan hanya media yang diperuntukkan sebagai ruang publik namun juga media sebagai bentuk industri, yang pada akhirnya menyebabkan televisi kerap melupakan tugas dan fungsi utamanya.

Tayangan dengan unsur mistis sering disajikan oleh media ditengah-tengah masyarakat dengan berbagai spekulasi. Media melihat bahwa mistis merupakan salah satu bagian dari kepercayaan masyarakat di Indonesia, dimana mistis dianggap sebagai sebuah cara untuk memaknai berbagai hal dalam kehidupan sehari-hari. Hal ini yang melatarbelakangi media menjadikan mistis sebagai alat atau bahan bagi pekerja televisi untuk dikomodifikasi.

Penelitian terdahulu mengenai komodifikasi, seperti ditulis Salim (Universitas Nasional, 2019) yang berjudul, "Komodifikasi Pertukaran Peran Gender pada Sinetron Dunia Terbalik di RCTI". Berdasarkan analisis dari hasil penelitian, pihak televisi melakukan komodifikasi terhadap pertukaran peran gender dalam Sinetron Dunia Terbalik di RCTI karena dinilai menarik dan memiliki unsur komersial, terbukti dari deretan iklan yang selalu hadir dalam sinetron tersebut, serta episode yang selalu diperpanjang. Penokohan yang dilakukan Sinetron Dunia Terbalik merupakan sebuah emansipasi kaum wanita yang selalu termarjinalkan, namun terkadang tayangan dalam sinetron tersebut kadang melampaui batas, namun hal itu dilakukan hanya sebagai daya tarik semata agar Sinetron Dunia Terbalik menarik dan diminati oleh pemirsa televisi.

Selanjutnya terdapat penelitian mengenai komodifikasi di televisi oleh Perdana (Universitas Bengkulu, 2017) dengan judul "Komodifikasi dalam Tayangan Televisi (Kajian terhadap Program Indonesia Idol 2014)". Hasil penelitian tersebut, komodifikasi dalam tayangan Indonesia Idol dilakukan secara menyeluruh.
Komodifikasi yang dilakukan menunjukkan bahwa ada persaingan untuk mendapatkan keuntungan. Program Indonesian Idol dianggap sebagai barang dagangan yang harus menarik perhatian banyak penonton dan laku untuk dipasarkan.

Terdapat penelitian lainnya oleh Chrysilla dan Kurniasari (Institut Teknologi dan Bisnis Kalbis, 2018) dengan judul "Komodifikasi Kemarahan dalam Tayangan Supertrap Trans TV", fokus penelitian ini terdapat pada komodifikasi reaksi dan ekspresi seseorang yang menjadi target. Khususnya pada reaksi dan ekspresi kemarahan yang digunakan sebagai gimmick untuk dijual dan dianggap sebagai bahan lelucon (komoditas). Hasil dari penelitian tersebut ialah terjadi pergeseran mitologi kemarahan. Kemarahan yang sebelumnya merupakan emosi manusia, tetapi oleh media massa dijadikan komoditas yang dipertontonkan.

Berikutnya terdapat penelitian oleh Thadi (Institut Agama Islam Negeri Bengkulu, 2020) dengan judul "Analisis Kritis Sinetron Religi: Antara Dakwah dan Kepentingan Komersial". Dari sudut pandang kritis, pengelola media memiliki kepentingan ekonomi politik. Akibat dari kepentingan tersebut muncul tradisi sinetron keagamaan yang bermuka dua. Di satu sisi media berkeinginan untuk menyampaikan dakwah, namun disisi lain yang jauh lebih dominan adalah media memiliki kepentingan komersil untuk mendapatkan keuntungan.

Terakhir, terdapat penelitian yang fokus pada komodifikasi mistis pada siaran televisi, yaitu "Strategi Komodifikasi Tim Program Jejak Leluhur Episode Susuk di ANTV". Hasil penelitian ini menunjukkan bahwa telah terjadi tiga jenis komodifikasi yaitu: konten, audiens dan pekerja yang dilakukan oleh tim program Jejak Leluhur. Tujuannya untuk menghasilkan program televisi yang menarik minat masyarakat agar rating meningkat dan mendapatkan pengiklan.

Jika penelitian terdahulu dikaitkan dengan penelitian ini, maka fokus penelitian ini adalah pada komodifikasi mistis yang disajikan oleh program reality show Garis Tangan di ANTV.

Berdasarkan penjelasan di atas maka perlu dilakukan penelitian komodifikasi terhadap tayangan mistis pada program reality show. Melihat betapa besarnya pengaruh televisi dalam membentuk jiwa penontonnya, televisi seharusnya lebih berhati-hati dalam menayangkan sebuah program, terutama program dengan muatan mistis. Bukan hanya mementingkan 
keuntungan semata. Mistis merupakan sebuah paham atau kepercayaan yang melekat pada kehidupan sehari-hari masyarakat, yang jika disampaikan dengan tidak baik akan menciptakan pemahaman yang buruk. Terutama di tengah masyarakat yang kini mudah terpengaruh dengan informasi hoax dan menyesatkan.

Guna melihat komodifikasi mistis dalam program reality show pencarian jodoh Garis Tangan di ANTV, penelitian ini menggunakan metode analisis semiotika Roland Barthes dengan melihat denotasi, konotasi dan mitos yang terdapat pada program tersebut.

Berdasarkan latar belakang masalah di atas, maka muncul beberapa pertanyaan penelitian, yaitu:

1. Bagaimana makna mistis yang ditampilkan dalam program reality show pencarian jodoh Garis Tangan di ANTV?

2. Bagaimana komodifikasi konten pada program reality show pencarian jodoh Garis Tangan di ANTV?

Mengacu pada pertanyaan di atas, maka muncul masalah penelitian, yaitu: Bagaimana komodifikasi mistis dalam program reality show pencarian jodoh Garis Tangan di ANTV?.

Penelitian ini dilakukan dengan tujuan mengkaji makna mistis dan praktik komodifikasi yang dilakukan ANTV pada program reality show pencarian jodoh Garis Tangan. Peneliti berharap penelitian ini dapat memberikan kontribusi yang positif bagi pengembangan wacana keilmuan tentang gejala sosial yang terjadi sehari-hari di sekitar kita. Selain itu, penelitian ini diharapkan dapat bermanfaat untuk akademisi, praktisi, mahasiswa jurnalistik, dan masyarakat umum.

\section{KAJIAN TEORITIS}

\subsection{Media Massa Televisi}

Informasi yang menjadi kebutuhan masyarakat dapat sampai ke tangan khalayak melalui media massa. Media massa menjadi sarana untuk menyampaikan segala informasi baik berupa fakta peristiwa dan pendapat. Yunus (2012 :27) mengatakan, media massa dapat diartikan sebagai segala bentuk media atau sarana komunikasi untuk menyalurkan dan memuplikasikan berita kepada publik atau masyarakat.

Media masa dibedakan menjadi tiga jenis yaitu media massa cetak, media massa elektronik (televisi dan radio) dan media online (Yunus, 2010:27). Badjuri
(2010:6) menjelaskan bahwa televisi menciptakan suasana tertentu karena penonton dapat menikmati acara dengan bersantai menyaksikan bebagai macam informasi, informasi yang disajikan televisi sangat jelas karena berupa gambar dan audio. Pesan di dalam televisi pun dapat langsung mempengaruhi sikap pemirsanya.

Televisi memiliki peran sentral dalam proses perubahan masyarakat dalam konteks sosial. Sebab, kecanggihan televisi yang begitu banyak dipandang mampu memenuhi kebutuhan manusia. Dalam persepktif ekonomi politik, media massa yang sering digunakan untuk mencari keuntungan (bisnis) dan melaksanakan agenda politik dari para pemangku kepentingan adalah televisi (Ibrahim, 2014: 3).

\subsection{Reality Show Pencarian Jodoh}

Reality show merupakan program yang menyajikan situasi seperti konflik, persaingan, atau hubungan berdasarkan realitas yang sebenarnya. Namun, pada dasarnya reality show tetap merupakan permainan (game) yang dikemas dengan drama atau hiburan (Morrisan, 2009:227). Nirmala mengatakan (2007), bahwa reality show berasal dari kata realitas. Maka, reality show adalah program televisi yang menyajikan situasi dramatis atau lucu namun tidak menggunakan naskah, merupakan kejadian yang sebenarnya (walau terkadang direncanakan), dan mengutamakan orang biasa dari pada aktor profesional.

Di Indonesia terdapat lima bentuk atau jenis reality show, yaitu: Pertama, Hidden Camera atau kamera tersembunyi. Program ini yang paling realitas karena menunjukkan seseorang yang dihadapkan pada situasi tertentu dengan apa adanya. Kedua, Competition Show. Melibatkan beberapa orang yang saling bersaing dalam sebuah kompetisi pertanyaan atau permainan. Ketiga, Relationship Show. Salah satu kontestan akan memilih satu orang dari sejumlah orang yang berniat menjadi pasangannya. Keempat, Fly On The Wall. Memperlihatkan kehidupan seharihari dari seseorang yang biasanya merupakan orang terkenal, mulai dari kegiatan pribadi hingga aktivitas profesionalnya. Terakhir, Mistis. Merupakan program yang berkaitan dengan hal-hal supranatural. Program ini menyajikan tayangan yang berkaitan dengan dunia gaib, paranormal, klenik, praktik spiritual magis, mistis, kontak dengan roh dan lain-lain (Morrisan, 2009:228).

Jika dikaitkan dengan penjelasan diatas maka Garis Tangan di ANTV merupakan reality show dengan 
jenis realitionship show, dimana dalam program tersebut akan mempertemukan laki-laki dan perempuan yang diharapkan memiliki kecocokan sebagai sepasang kekasih. Selain relatioship show, Garis Tangan di ANTV juga memasukkan unsur mistis dimana untuk melihat kecocokan antara laki-laki dan perempuan, pembawa acara yaitu Uya Kuya menggunakan kemampuan dua orang indogo untuk melihat masa lalu calon pasangan yang berkaitan dengan hal-hal supranatural.

\subsection{Komodifikasi Mistis}

Dalam teori ekonomi politik terdapat tiga konsep dasar, diantaranya: Komodifikasi, Spasialisasi dan Sturkturasi. Komodifikasi adalah transformasi dari nilai guna menjadi nilai tukar. Spasialisasi merupakan upaya media massa untuk menyajikan produk di hadapan khalayak tanpa ada batasan ruang dan waktu. Komodifikasi dan spasialisasi dalam media massa pada akhirnya menghasilkan penyeragaman ideologi secara terstruktur (strukturasi). Setiap agen sosial mampu bertindak melayani apa yang menjadi kebutuhan pasar (Mosco, 2009:126).

Dalam komodifikasi, informasi dan hiburan yang merupakan produk dari media dijadikan sebagai barang yang dapat dipertukarkan dan bernilai ekonomis. Pada praktisnya, seluruh awak media dilibatkan dalam proses transformasi ini, untuk mendagangkan dan mendistribusikan komoditas tersebut kepada khalayak atau audiens (Ibrahim, $2014: 12$ ).

Syarat komodifikasi adalah adanya perubahan pada barang dagangan melalui pengemasan dengan nilai citra yang tinggi. Semua bentuk informasi dan hiburan dikemas sedemikian rupa agar bernilai ekonomis. Televisi sebagai salah satu lembaga penyiaran melakukan upaya komodifikasi dan komersialisasi pada berbagai aspek yang dipandang mampu meningkatkan keuntungan (Mosco, 2009:30).

Terdapat beberapa bentuk komodifikasi, yaitu:1. The Commodification of Content atau proses komodifikasi dalam komunikasi yang melibatkan transformasi pesan menjadi produk berharga (Mosco, 2009:133), 2. The Audience Commodity, perusahaan media massa memproduksi khalayak atau penonton dan memberikannya kepada pengiklan, (Mosco, 2009: 136), 3. The Commodification of Labor, proses komodifikasi dimana pemodal secara terpisah bertindak hanya sebatas konsepsi dan terpisah dari eksekusi (Mosco, 2009:139), 4. Immanent Commodification, komoditas memproduksi atau menghasilkan komo- ditas baru atau komoditas imanen dan bagaimana komoditas baru diproduksi melalui asosiasi diantara beragam komoditas yang berbeda, pembahasan dimulai dengan khalayak sebagai komoditas (Mosco, 2009:141), 5. Externalizing Commodification, komodifikasi yang diperluas ke area intitusional. Jadi bukan hanya pada media dan telekomunikasi tetapi juga pendidikan, museum, taman bermain, perpustakaan, dan sebagainya (Mosco, 2009:143).

Ketika pelaku media mengubah pesan melalui teknologi kedalam interpretasi pesan yang penuh makna saat itulah komodifikasi konten atau isi dimulai. Pesan atau konten tersebut dibuat menjadi marketable. Komodifikasi seperti ini dilakukan sebagai upaya media massa untuk menarik perhatian dan minat khalayak dengan beragam nilai citra yang dipandang sesuai dengan selera pasar (Mosco 2009:133). Komodifikasi konten kerap menambahkan hal-hal sensasional yang menarik perhatian pada setiap pesannya, meskipun kadang diluar esensi suatu acara.

Mistis adalah suatu hubungan antara realitas kebatinan dengan kesadaran manusia yang lebih mengutamakan kekuatan pengindraan dalam menafsirkan realitas (Bungin, 2005). Walaupun memiliki dampak yang tidak terlalu mencerdaskan masyarakat, pada kenyataanya tayangan mistis begitu disukai. Lantaran konsumen media di Indonesia masih berbasis tradisional dan lebih menyukai informasi dengan unsur takhayul sebagai konstruksi besar pengetahuan mereka mengenai hidup, dan pengetahuan yang diperoleh selama hidup (Bungin, 2007:327).

Morissan mengatakan, program berbentuk mistis adalah wujud dari program yang di dalamnya terdapat hal yang berkaitan dengan supranatural atau dunia gaib, paranormal, klenik, praktis, spiritual magis atau perdukunan, kontak dengan roh dan sebagainya. Program ini lebih banyak mengeksploitasi dunia lain yang berhubungan dengan roh, makhluk halus, dan kekuatan supranatural seseorang (Morissan, 2009 :218-219). Seperti Garis Tangan di ANTV yang menggunakan mistis sebagai daya tarik dari programnya. Program dengan jenis relationship show yang memiliki tujuan mempertemukan antara lakilaki dan perempuan untuk dijodohkan justru dikaitkan dengan hal-hal mistis.

\subsection{Mistis Menurut Perspektif Agama}

Apabila kita membuka lembaran kitab suci AlQur'an, tepatnya setelah surah Al-Fatihah yang 
merupakan induk Al-Qur'an sekaligus kesimpulannya, maka hal pertama yang ditemukan adalah uraian tentang fungsi Al-Qur'an sebagai hudan/petunjuk bagi orang-orang bertaqwa, sedangkan sifat pertama mereka adalah: Yu'minuuna Bi Al-Gaib (percaya yang gaib). Antonim dari kata syahadat atau yang tidak hadir adalah gaib. Apapun yang tidak dapat disaksikan juga merupakan gaib, bahkan sesuatu yang tidak terjangkau oleh panca indra manusia juga merupakan gaib. Banyak hal yang gaib bagi manusia, serta beragam pula tingkat kegaibannya (Shihab, 2000:10).

Dalam setiap agama dan ajaran kepercayaan dijelaskan mengenai keyakinan adanya sesuatu yang metafisik. Bahkan, sebetulnya mempercayai sesuatu yang metafisik adalah suatu fitrah bagi manusia. Agama-agama samawi mengajarkan keyakinan tentang adanya sesuatu yang gaib melalui Nabi dan Kitab Sucinya. Salah satu agama samawi tersebut adalah Islam. Al-Qur'an sebagai sumber utama ajaran Islam dengan gamblang menyebutkan bahwa yakin pada yang gaib adalah salah satu ciri orang yang beriman (Morgan, 1985:439).

\subsection{Semiotika Model Roland Barthes}

Coble and Jansz mengatakan bahwa semiotik merupakan ilmu tentang tanda atau studi tentang bagaimana sistem penandaan berfungsi. Secara garis besar, semiotik memiliki definisi ilmu tanda dan segala yang berhubungan dengannya, mulai dari cara berfungsinya, hubungannya dengan kata lain, pengiriman, dan penerimaannya oleh mereka yang menggunakannya (Sobur, 2009:16). Pada dasarnya analisis semiotik digunakan untuk merasakan sesuatu yang aneh dan patut dipertanyakan lebih lanjut mengenai sebuah fenomena. Tujuan utama dari semiotika media adalah mempelajari bagaimana media massa menciptakan atau mendaur ulang tanda untuk tujuannya sendiri. Cara ini dilakukan dengan pertanyaan, seperti apa yang dimaksudkan direpresentasi oleh sesuatu, bagaimana makna digambarkan, dan mengapa bisa memiliki makna sebagaimana ia tampil (Sobur, 2009:117).

Barthes mengatakan bahwa terdapat dua tingkat penandaan dalam semiotik yaitu denotasi dan konotasi. Tingkat penandaan pertama adalah denotasi yang menjelaskan hubungan penanda dan petanda pada realitas, menghasilkan makna eksplisit, langsung dan pasti. Denotasi memiliki referen realitas eksternal yang harus ditemukan terlebih dahulu untuk kemudi- an dipersepsi kembali pada tingkat penandaan kedua. Berbeda dengan denotasi, konotasi adalah tingkat pertandaan yang menjelaskan hubungan penanda dan petanda yang di dalamnya beroperasi makna yang tidak eksplisit, tidak langsung dan tidak pasti (Piliang, 2010:261).

\section{METODE PENELITIAN}

Penelitian ini menggunakan paradigma konstruktivis. Dalam pandangan konstruktivisme media turut andil dalam mengkonstruksikan fakta. Eriyanto mengatakan (2012:36), media bukan hanya sekedar saluran yang bebas, namun juga subjek yang mengkonstruksi realitas, lengkap dengan pandangan, bias, dan pemihakannya.

Metodologi atau pendekatan yang digunakan dalam penelitian ini adalah kualitatif. Pendekatan kualitatif merupakan salah satu metode penelitian yang memiliki tujuan untuk mendapatkan pemahaman tentang kenyataan melalui proses berpikir induktif. Berdasarkan pendekatan penelitian yang digunakan, jenis penelitian ini bersifat deskriptif. Jenis riset ini bertujuan membuat deskripsi secara sistematis, faktual, dan akurat tentang fakta-fakta dan sifat-sifat populasi atau objek tertentu (Kriyantono, 2010 :68-69).

Metode yang digunakan dalam penelitian ini adalah semiotika yang dikembangkan oleh Roland Barthes. Salah satu ciri semiotika Roland Barthes adalah menelusuri makna dengan pendekatan budaya yaitu semiotik makro, dimana Barthes memberikan makna pada sebuah tanda berdasarkan kebudayaan yang melatarbelakangi munculnya makna tersebut. Maka makna dalam tataran mitos dapat diungkap sesuai dengan keunggulan semiotik Roland Barthes yang terkenal dengan elemen mitosnya.

Bahan penelitian yang digunakan dalam penelitian ini adalah seluruh tayangan program pencarian jodoh Garis Tangan di ANTV, dari tayangan tersebut akan dianalisis sesuai dengan fokus permasalahannya melalui unit analisis. Arikunto (2013:187) mengatakan, unit analisis dalam penelitian merupakan satuan tertentu yang diperhitungkan sebagai subjek penelitian. Dalam penelitian ini, digunakan keseluruhan unsur dalam tayangan program pencarian jodoh Garis Tangan di ANTV sebagai unit analisis yaitu teks dan scene atau audio visual (video) pada program reality show Garis Tangan di ANTV. Peneliti akan memfokuskan penelitian pada gimmick mistis atau adegan dengan muatan mistis dalam tayangan tersebut. 


\subsection{Populasi dan Sampel}

Populasi dalam penelitian ini adalah tayangan program pencarian jodoh Garis Tangan di ANTV, 11 Oktober hingga 10 November 2019;

Tabel 1. Populasi Penelitian

\begin{tabular}{|c|c|c|}
\hline No Tanggal Tayang & Judul & Topik \\
\hline 1. 11 Oktober 2019 & $\begin{array}{l}\text { Bersetubuh Dengan } \\
\text { Begu Ganjang! }\end{array}$ & $\begin{array}{l}\text { Interaksi manusia dan } \\
\text { makhluk gaib }\end{array}$ \\
\hline 2. 12 Oktober 2019 & $\begin{array}{l}\text { Dua bulan } \\
\text { Disembunyikan } \\
\text { Makhluk Gaib! }\end{array}$ & $\begin{array}{l}\text { Interaksi manusia dan } \\
\text { makhluk gaib }\end{array}$ \\
\hline 3. 13 Oktober 2019 & $\begin{array}{l}\text { Hampir Gila } \\
\text { Diganggu } \\
\text { Genderuwo! }\end{array}$ & $\begin{array}{l}\text { Teror makhluk gaib } \\
\text { pada manusia }\end{array}$ \\
\hline 4. 18 Oktober 2019 & $\begin{array}{l}\text { Akibat Melanggar } \\
\text { Ritual Gaib! }\end{array}$ & $\begin{array}{l}\text { Interaksi manusia dan } \\
\text { makhluk gaib }\end{array}$ \\
\hline 5. 19 Oktober 2019 & $\begin{array}{l}\text { Balas Dendam } \\
\text { Dukun Bertindak! }\end{array}$ & $\begin{array}{l}\text { Interaksi manusia dan } \\
\text { makhluk gaib }\end{array}$ \\
\hline 6. 20 Oktober 2019 & Perjanjian Gaib! & $\begin{array}{l}\text { Interaksi manusia dan } \\
\text { makhluk gaib }\end{array}$ \\
\hline 7. 25 Oktober 2019 & Jimat Pembawa Sial! & $\begin{array}{l}\text { Interaksi manusia dan } \\
\text { makhluk gaib }\end{array}$ \\
\hline 8. 26 Oktober 2019 & $\begin{array}{l}\text { Ritual dan Muntah } \\
\text { Darah! }\end{array}$ & $\begin{array}{l}\text { Interaksi manusia dan } \\
\text { makhluk gaib }\end{array}$ \\
\hline 9. 27 Oktober 2019 & Dinikahi Batu Nisan! & $\begin{array}{l}\text { Teror makhluk gaib } \\
\text { pada manusia }\end{array}$ \\
\hline $\begin{array}{l}\text { 10. } 3 \text { November } \\
2019\end{array}$ & $\begin{array}{l}\text { Diserang } \\
\text { Genderuwo! }\end{array}$ & $\begin{array}{l}\text { Teror makhluk gaib } \\
\text { pada manusia }\end{array}$ \\
\hline $\begin{array}{l}\text { 11. } 10 \text { November } \\
2019\end{array}$ & Teror Serangan Gaib! & $\begin{array}{l}\text { Teror makhluk gaib } \\
\text { pada manusia }\end{array}$ \\
\hline
\end{tabular}

Berdasarkan tabel tersebut maka jumlah populasi pada penelitian ini adalah 11 episode tayangan program pencarian jodok Garis Tangan di ANTV, yang terdiri dari dua topik yaitu: 1 . Interaksi manusia dan makhluk gaib, 2 . Teror makhluk gaib pada manusia.

Mengenai teknik sampling, Sugiyono (2013:218-219) menyatakan, purposive sampling adalah teknik pengambilan sampel sumber data dengan pertimbangan tertentu. Purposive sampling merupakan teknik pengambilan sampel yang tepat untuk penelitian ini karena teknik pengambilan sampel ini berdasarkan kapasitas dan kapabilitas dengan pertimbangan peneliti yaitu tujuan penelitian, pemenuhan unsurunsur analisis semiotika model Rolland Barthes, serta pertimbangan khusus lainnya seperti unsur mistis.

Pada penelitian ini ditetapkan dua episode sebagai sampel penelitian, dimana sampel diambil berdasarkan jumlah topik. Episode tersebut dipilih sebagai sampel penelitian karena sesuai dengan tujuan penelitian yaitu untuk mengkaji makna mistis yang ditampilkan dan praktik komodifikasi pada program reality show pencarian jodoh Garis Tangan di ANTV.
Berikut episode yang akan digunakan sebagai sampel dalam penelitian (seperaati pada Tabel 2).

Tabel 2. Sampel Penelitian

\begin{tabular}{cccc}
\hline No & $\begin{array}{c}\text { Tanggal } \\
\text { Tayang }\end{array}$ & Judul & Topik \\
\hline 1. & 11 Oktober & Bersetubuh & Interaksi manusia \\
& 2019 & Dengan Begu & dan makhluk gaib \\
& & Ganjang! & \\
2. & 27 Oktober & Dinikahi Batu & Teror makhluk gaib \\
& 2019 & Nisan! & pada manusia \\
\hline
\end{tabular}

\subsection{Teknik Pengumpulan Data}

Sugiyono yang dikutip oleh Prastowo (2013:208) mengatakan, teknik pengumpulan data merupakan langkah yang paling strategis dalam penelitian karena tujuan utama penelitian adalah mendapatkan data. Sugiyono mengatakan (2013:255), ada beberapa macam teknik pengumpulan data, yaitu observasi (pengamatan), interview (wawancara), kuesioner (angket), dokumentasi atau gabungan dari keempatnya.

Berdasarkan pernyataan di atas, maka teknik pengumpulan data yang digunakan dalam penelitian ini adalah dokumentasi berupa rekaman dari tayangan pencarian jodoh Garis Tangan di ANTV.

\subsection{Teknik Analisis Data}

Menurut Sugiyono (2013:89), "Analisis data merupakan proses mencari dan menyusun secara sistematis data yang diperoleh dari hasil wawancara, catatan lapangan dan dokumentasi, dengan cara mengorganisasikan data ke dalam kategori, menjabarkan ke dalam unit-unit, melakukan sintesa, menyusun ke dalam pola, memilih mana yang penting dan yang akan dipelajari, juga membuat kesimpulan sehingga mudah dipahami oleh diri sendiri maupun orang lain". Berdasarkan penjelasan tersebut, peneliti menganalisis dengan pendekatan kualitatif dengan menggunakan metode semiotika model Roland Barthes.

\section{HASIL PENELITIAN}

\subsection{Hasil Penelitian}

$\begin{array}{ll}\text { Sampel } & : 1 \\ \text { Episode } & : \text { Bersetubuh Dengan Begu Ganjang! } \\ \text { Topik } & : \text { Interaksi manusia dan makhluk gaib } \\ \text { Tanggal Tayang: } & \text { 11 Oktober } 2019\end{array}$




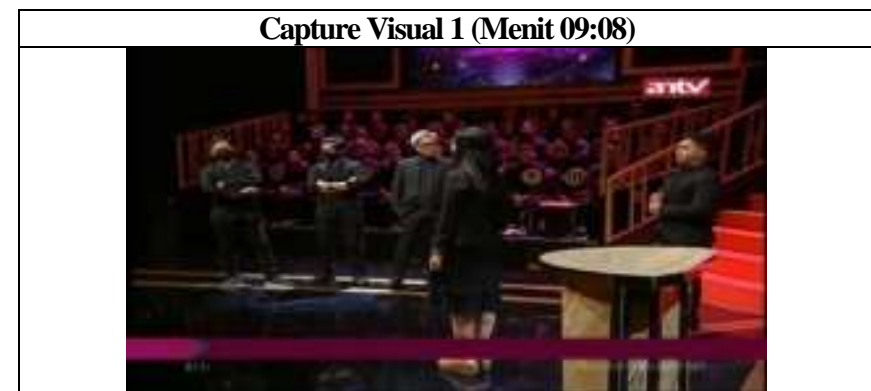

Denotasi: dua orang pria berpakaian serba hitam dengan penutup wajah mulai dari hidup hingga dagu berdiri sambil menyilangkan tangan diatas dada mereka. Disamping mereka berdiri pria lainnya dengan rambut putih dan kacamata berpakaian serba hitam memasukkan tangan kedalam saku celananya. Dibelakang mereka duduk beberapa pria berpakaian serba hitam dan menutup wajah bagian mata dengan tanda nomor dihadapan mereka. Diarah kiri hadapan mereka berdiri seorang wanita berambut panjang melebihi bahu dan berpakaian serba hitam. Pria lainnya dengan pakaian serba hitam berdiri disamping kanan wanita tersebut.

\begin{tabular}{|c|c|c|}
\hline & Capture Visual 2 (Menit 13:55) \\
\hline & & \\
& & \\
& &
\end{tabular}

\begin{tabular}{|c|c|c|}
\hline Capture Visual 3 (Menit 18:29) \\
\hline & \\
& & \\
\hline
\end{tabular}

Arbi: kalo tadi kita berbicara unsur dingin, tanah dan air, kalau saya lihat unsurnya itu ada unsur yang sangat panas.

Uya: panas justru? oke

Arbi: api ? iya ada api

Denotasi: seorang pria mengatakan bahwa ia melihat sesuatu pada diri seorang wanita. Pria lainnya menebak apa yang dilihat oleh pria satunya.
Arbi: tapi bukan dendam, ini beda banget unsurnya.

Uya: api mungkin?
Konotasi: Feby berdiri menghadap ke arah para kandidat pria dan Uya Kuya sebagai kandidat wanita yang akan dijodohkan.

Mitos: kepercayaan bahwa dalam diri seseorang terdapat beberapa energi seperi, api, air, tanah, logam dan kayu yang berkaitan dengan kepribadian seseorang. Hanya orang-orang dengan kemampuan khusus seperti seorang hypnoterapi yang dapat melihat atau merasakan energi tersebut

Denotasi: dua orang pria dengan penutup wajah bagian hidung hingga dagu dan seorang pria dengan rambut putih dan kaca mata menggunakan pakaian serba hitam berdiri dan melihat kearah kiri mereka. Di belakang mereka duduk beberapa pria berpakaian serba hitam dan penutup wajah bagian mata dengan tanda nomor dihadapan mereka. Seorang wanita berdiri dibelakang meja sambil mengangkat sebelah tangan dan menghadap kearah kirinya.

Konotasi: Feby sebagai kandidat wanita yang akan dijodohkan mencoba menjelaskan mengenai siapa dirinya dan bagaimana masa lalunya kepada para kandidat pria dan Uya Kuya. sejenisnya adalah ilmu sihir atau ilmu hitam yang diharamkan oleh agama. Biasanya orang menggunakan hal ini untuk mewujudkan suatu keinginan secara instan

Denotasi: seorang wanita dengan penutup wajah mulai dari hidung hingga dagu melihat kearah kanan. Dibelakang wanita tersebut terlihat angka 12 dan bayangan orang lain. Terdapat teks "memasang beberapa pemikat untuk menarik perhatian lawan jenis"

Konotasi: Feby mengatakan bahwa ia memasang pemikat pada tubuhnya untuk menarik perhatian lawan jenis.

Konotasi: kemampuan Arbi sebagai seorang hypnoterapi yang mampu membaca aura dalam diri Feby.

(a) melihat atau merasakan Feby: pas saya diajak ternyata memang suami saya itu memang dipantek sama selingkuhannya itu. Kayak digunaguna biar nurut sama selingkuhannya

Uya: kata siapa?

Feby: saya sempat ke tempat dukun kaya

dulu.

Uya: oke

Denotasi: seorang wanita menceritakan kejadian tentang mantan suaminya. Seorang pria bertanya keyakinan wanita mengenai kejadian tersebut

Konotasi: Keyakinan Feby akan alasan suaminya yang dulu berselingkuh adalah karena sudah di guna-guna oleh wanita ( Aurdio 3 Feby: Saya sempet merasakan mistis juga mas Uya, dirumah saya sendiri. Itu kaya disetubuhi sama jin. Memang saya ada pasang di badan sih.

Uya: pasang apa?

Feby: Emm.. susuk gitu.

Denotasi: seorang wanita mengatakan pada host bahwa ia memiliki pengalaman disetubuhi oleh makhluk gaib dan mengaku menggunakan sesuatu di tubuhnya.

Konotasi: Feby merasa ia pernah disetubuhi oleh jin dirumahnya sendiri. Penyebabnya adalah karena ia memasang susuk pada tubuhnya.

Mitos: susuk merujuk pada suatu cara memasukkan benda asing ke dalam tubuh seseorang secara spiritual untuk mendapatkan suatu kelebihan. Penggunaan susuk didasari oleh kepercayaan terhadap adanya makhluk gaib yang dapat ber interaksi dengan manusia. Sehingga saat seseorang telah menggunakan susuk, ia akan mendapatkan pengalaman spiritual lainnya. lain. Keyakinan ini muncul setelah Feby mengunjungi dukun. 


\begin{tabular}{|l|l|}
\hline Capture Visual 4 (Menit 20:31) \\
\hline & \\
& \\
\hline
\end{tabular}

Denotasi: seorang pria berpakaian serba hitam memegang tangan seorang wanita yang menggunakan penutup wajah dari hidung hingga dagu. Terdapat teks "Rudy mencoba menerawang kehidupan masa lalu Feby (kandidat wanita)"

Konotasi: Rudy memegang tangan Feby dan merasakan garis tanganya untuk melihat bagaimana masa lalu Feby.
Audio 4

Rudy: Boleh saya pinjem tangannya? haha kamu hypersex. Ada makhluk tinggi besar, tidak besar si, seperti kurus. Pernah berhubungan dengan dia, warnanya hitam Uya: ini bukan manusia ya?

Rudy: bukan, seperti sejenis begu ganjang.

Denotasi: seorang pria mengatakan hasil pengamatannya tentang masa lalu seorang wanita dan mengatakan bahwa ia melihat sosok gaib

Konotasi: Rudy meyakinkan bahwa Feby adalah seorang hypersex yang juga pernah berhubungan dengan makhluk gaib yaitu begu ganjang.

Mitos : kepercayaan bahwa seorang indigo atau orang-orang yang memiliki kemampuan khusus dianggap dapat melihat masa lalu dan masa depan. Kemampuan itu dapat dilakukan dengan beberapa cara, salah satunya menerawang melalui tangan.

Capture Visual 5 (Menit 20:31)

Denotasi: seorang pria dengan rambut putih dan kacamata berpakaian serba hitam memasukkan tangannya kedalam saku celana dan berdiri melihat ke arah kirinya. Dibelakangnya duduk beberapa pria dengan pakaian serba hitam dan penutup wajah bagian mata dengan nomor dihadapanya. Seorang wanita dengan pakaian serba hitam dan penutup wajah mulai dari hidung hingga dagu beridiri di sisi belakang meja sambil melihat kerah kananya.

Konotasi: Uya kuya sebagai pembawa acara beribicara dengan Feby sebagai kandidat wanita yang akan di jodohkan

Audio 5

Uya: saat kamu merasa ada makhluk halus yang melakukan hal tersebut sama kamu kenapa kamu menikmati?

Feby: saya menikmati, saya pikir itu hanya mimpi basah biasa, ternyata memang yang bersetubuh dengan saya itu makhluk halus.

Uya: jin?

Feby: iya

Denotasi: seorang pria menanyakan pendapat seorang wanita mengenai suatu hal. Seorang wanita mengatakan pendapatnya mengenai suatu kejadian tentang dirinya.

Konotasi: Uya kuya menanyakan keyakinan dan alasan Feby menikmati pengalamannya disetubuhi oleh makhluk gaib.

Mitos: kepercayaan mengenai adanya makhluk gaib dan kemampuan kita untuk berinteraksi dengan mereka. Makhluk gaib adalah istilah yang digunakan untuk menyebut makhluk hidup yang eksistensinya tidak dapat dijangkau oleh panca indra manusia.

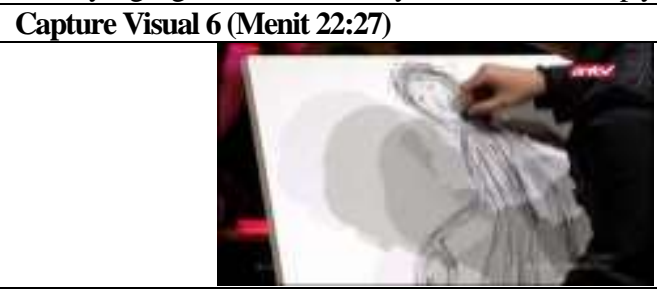

Denotasi: sebuah tangan berada di atas media berwarna putih.

Konotasi: Rudy sedang menggambarkan sosok makhluk gaib yang bentuknya tinggi kurus dengan mata merah.

Audio 6

Uya: saya gak habis pikir, kamu kok menikmati berhubungan dengan makhluk seperti itu. Mungkin dari tadi kamu belum liat tapi saya dari tadi melihat apa yang Rudy gambar. Nanti kamu akan melihat sosok seperti apa yang melakukan hal tersebut sama kamu setiap malam jumat jam satu malam

\section{Denotasi: seorang pria menjelaskan keheranannya}

Konotasi: Keterkejutan Uya kuya akan bagaimana bentuk makhluk gaib yang menyetubuhi Feby dan heran kenapa Feby meningkmatinya.

Mitos: kemampuan lain yang dipercaya dimiliki oleh seorang indigo adalah mampu melihat makhluk-makhluk tak kasat mata, lalu menggambarkannya diatas media tertentu. Begu ganjang jika diartikan secara sederhana adalah hantu/roh panjang. Begu ganjang konon dipelihara untuk niat membunuh atau mencelakai orang lain.

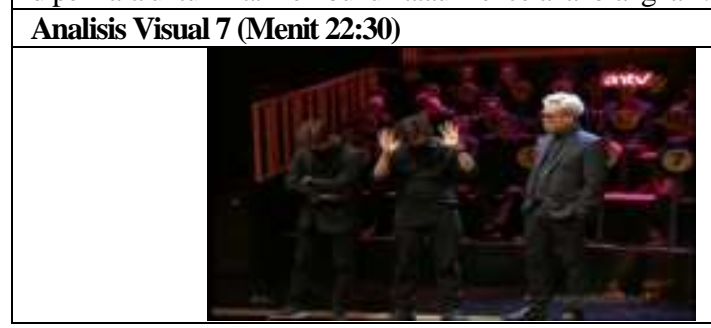

\section{Analisis Audio 7}

Uya: komentar kamu Tyson setelah mendengar ini, kamu tertarik apa justru mundur ?

Tyson: awalnya saya sempat simpatik, ceritanya, trus suaminya selingkuh. Karena apa yang dia ceritakan itu persis seperti apa yang saya alami. Tapi ke sinian saya pahami ceritanya dia lebih menikmati hubungan dengan makhluk yang digambarkan, jadi saya ngeri, aku mundur. 
Denotasi: tiga orang pria berpakaian serba hitam, yang pertama berdiri dan menggunakan penutup wajah mulai dari hidung hingga dagu dengan melipat tangan di depan dadanya sambil melihat kebawah. Yang kedua berdiri menggunakan penutup wajah mulai dari hidung hingga dagu dengan mengangkat kedua tangannya sambil melihat kebawah. Pria ketiga berambut putih dan kacamata memasukkan tangannya kedalam saku sambil melihat kea rah kananya. Dibelakang mereka duduk beberapa pria dengan pakaian serba hitam dan penutup wajah bagian mata dengan tanda nomor dihadapan mereka.

Konotasi: Uya kuya menanyakan pendapat Tyson dan Doni sebagai kandidat pria yang akan dijodohkan dengan Feby. Tyson mengangkat tangan karena menyerah untuk dijodohkan, sedangkan Doni hanya bisa menunduk kebingungan.

Mitos: seseorang yang memiliki kepercayaan dan pengalaman mengenai hal-hal spiritual dan gaib akan kesulitan untuk berinteraksi dan mendapatkan pasangan karena orang-orang akan ketakutan dan menghindarinya.

Analisis komodifikasi pada sampel satu dapat dijelaskan bahwa dalam proses perjodohan, kriteria yang digunakan untuk melihat kecocokkan adalah aura dan pengalaman mistis dari para kandidat. Hal tersebut tidak lumrah dilakukan dalam proses pengenalan untuk program pencarian jodoh. Uya Kuya selaku host dan kedua expertise selalu mengarahkan topik obrolan kearah mistis. Dapat dilihat pada setiap pertanyaan yang diajukan oleh mereka. Dimulai dari membaca aura yang selanjutnya mengarah pada pengalaman mistis yang dirasakan oleh kandidat wanita bernama Feby. Skenario perjodohan makin mengarah ke unsur mistis ketika Rudy seorang indigo mulai membaca garis tangan Feby dan menggambar sosok makhluk gaib yang selama ini 'menempel' pada Feby.

Garis Tangan merupakan program reality show pencarian jodoh, maka sudah seharusnya mereka membantu para kandidat agar memiliki kesempatan bertemu dan mengenal pasangan mereka lewat program ini. Namun, yang disajikan justru kisah-kisah menyeramkan yang membuat kandidat wanita bernama Feby kehilangan kesempatan untuk bertemu dan mengenal pasangannya. Hal ini dapat dilihat dari analisis visual 7 dimana seorang kandidat pria bernama Tyson menyerah untuk mengenal Feby lebih jauh. Setelah mendengarkan cerita mistis yang dialami oleh Feby.
Sampel
$: 2$
Episode
: Dinikahi Batu Nisan!
Topik
: Teror makhluk gaib pada manusia

Tanggal Tayang: 27 Oktober 2019

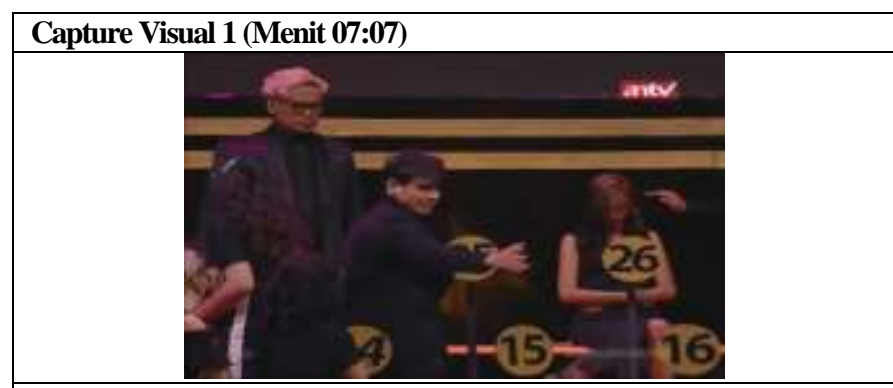

Denotasi: seorang pria berpakaian serba hitam dengan rambut berwarna putih dan menggunakan kacamata berdiri dan melihat ke arah kiri bawah. Seorang pria berpakaian serba hitam menunjuk kearah kiri bawah. Seorang wanita berpakaian serba hitam dengan penutup wajah bagian mata dan tanda nomor 26 dihadapannya duduk dengan melipat kedua tangan sambil menunduk. Terdapat tanda nomor 14,15 dan 16 didepan mereka.

Konotasi: Kandidat wanita nomor 26 kerasukan sosok makhluk gaib pocong, Rudy menjelaskan itu bisa terjadi karena Anggi.

Mitos: kepercayaan akan adanya makhluk gaib yang dapat merasuki tubuh manusia Pose melipat tangan dias perut dianggap seperti sosok gaib yaitu pocong.

\section{Audio 1}

Arbi: ini ada hubungannya sama Anggi, ini kayaknya sosok, kalo tangannya kayak gini sosoknya pocong. Uya: oke, sekarang ada juga terjadi sebelah sini, kenapa dia mengeram seperti ini ? atau langsung saja kita panggilkan sahabat saya seorang indigo, Rudy Rudy: iya ini dibawa sama dia.

Denotasi: seorang pria menjelaskan tindakan yang sedang dilakukan oleh seorang wanita. Pria lain bertanya dan memanggil seseorang.

Konotasi: Anggi diyakini sebagai penyebab kandidat wanita nomor 26 kerasukan pocong. Hal tersebut dikatakan oleh Arbi dan ditegaskan kembali oleh Rudy. 


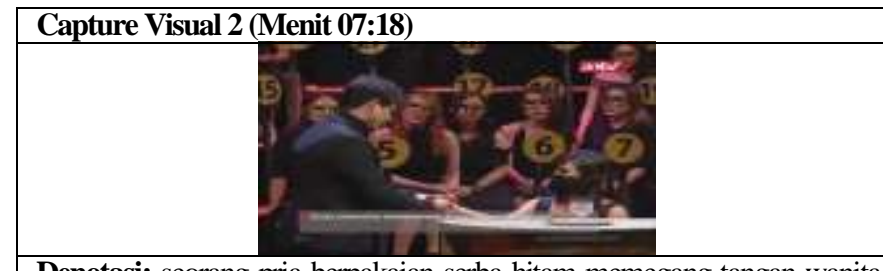

Denotasi: seorang pria berpakaian serba hitam memegang tangan wanita berpakaian serba hitam yang menggunakan penutup wajah mulai dari hidung hingga dagu. Dibelakang mereka terdapat beberapa wanita berpakaian serba hitam dengan penutup wajah bagian mata yang duduk dengan tanda nomor dihadapan mereka.Terdapat teks "Rudy mencoba menerawang Anggi (kandidat wanita)"

Konotasi: Rudy menerawang masa lalu dan apa yang ada dalam diri Anggi dengan melihat dari garis tangannya.

\section{Audio 2}

Rudy: Boleh saya cek kamu. Kamu itu digantung waris, saya lihat pemakaman seperti batu nisan, jadi dia ini dibuat supaya orang itu menjauh dari dia

Denotasi: seorang pria menjelaskan alasan dari apa yang terjadi pada seorang wanita.

Konotasi: Rudy mengatakan alasan Anggi selama ini sulit mendapatkan jodoh dan selalu dijauhi oleh orang lain adalah karena Anggi digantung waris oleh seseorang.

Mitos: kepercayaan mengenai seorang indigo atau orang berkemampuan khusus yang dapat melihat masalalu orang lain melalui garis tangan. Mereka juga dapat melihat ganguan spiritual dari makhluk gaib terhadap kehidupan berinteraksi antar manusia.

\begin{tabular}{|l|l|}
\hline Capture Visual 3(Menit 08:17) \\
\hline
\end{tabular}

Denotasi: seorang pria berpakaian serba hitam dengan rambut putih dan kacamata sedang menutup mulutnya dengan sebelah tangannya.

Konotasi: Uya kuya mencium sesuatu yang tidak sedap, ia langsung menutup hidung dan mulutnya
Uya: tunggu sebentar, kenapa ni saya tiba-tiba kaya mencium bau sangit

Rudy: bau sangit itu pertanda pocong, pocong datang
Denotasi: seorang pria mengatakan bahwa iya mencium bau sesuatu yang mengganggu. Pria lain menjelaskan bau apa itu.

Konotasi: Munculnya bau sangit secara tiba-tiba dikatakan oleh Rudy sebagai penyebab datangnya sosok pocong.

Mitos: kepercayaan pada adanya makhluk gaib yang akan menunjukkan tanda apabila ia datang. Salah satunya adalah tanda bau sangit yang menandakan kedatangan sosok gaib pocong.

Capture Visual 4 (Menit 09:08)

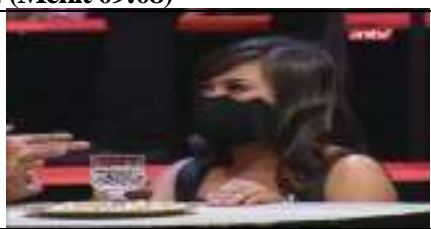

Denotasi : seorang wanita berpakaian serba hitam dengan penutup wajah mulai dari hidung hingga dagu sedang duduk sambil melihat kearah kanannya. Dihadapannya terdapat sebuah gelas yang berisi air dan tangan seseorang.

Konotasi: Air dihadapn Anggi adalah perantara yang digunakan untuk relaksasi
Mitos: kepercayaan akan adanya makhluk gaib dan hal-hal yang bernuansa spiritual membuat orang mendatangi tempat-tempat seperti dukun (orang pintar). Peran dukun sendiri dianggap sebagai salah satu fenomena yang diyakini kekuatan magisnya.

\section{Capture Visual 5(Menit 10:53)}

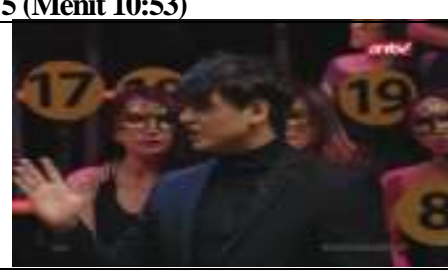

Denotasi: seorang pria berpakaian serba hitam sedang membuka mulutnya sambil mengangkat sebelang tanganya dan menghadap kearah kananya. Dibelakangnya terdapat beberapa wanita berpakaian serba hitam dan penutup wajah bagian mata dengan tanda nomor dihadapan mereka.

Konotasi: Rudy mencoba menjelaskan mengenai pemahaman dan hasil pengamatannya

\section{Audio 4}

Anggi: saya sudah sebelas tahun single parent, trus selama ini saya selalu gagal dalam hubungan asmara mas setelah bercerai. Mau nikah gagal, mau nikah gagal. Dan saya sempet ke orang pintar.

Denotasi: seorang wanita menjelaskan tentang hubungan asmaranya dan mengatakan bahwa ia pernah mendatangi seseorang

Konotasi: Anggi mendatangi orang pintar (dukun) karena keputus asaanya yang selalu gagal mendapatkan

\section{Audio 5}

Rudy: yang biasa terjadi, ketika seorang mantan yang tidak rela atau punya dendam kepada mantanya lagi gitu loh.

Uya: jadi maksdunya ini mantan suaminya dia?

Rudy: iya, jadi supaya Anggi ini tidak disentuh pria lain.

Supaya hidupnya tidak bahagia tidak punya cinta, seperti itu.

Denotasi: seorang pria menjelaskan tentang alasan kenapa seorang wanita sulit mendapatkan pasangan hidup. Pria lainnya bertanya untuk memastikan alasan tersebut

Konotasi: Mantan suami Anggi melakukan gantung waris yang menyebabkan Anggi sulit mendapatkan pasangan. Alasanya karena ia tidak rela dan dendam kepada Anggi.

Mitos: kepercayaan bahwa seseorang bisa mengirim kutukan atau santet kepada orang lain dengan alasan balas dendam. Kutukan atau santet sendiri merupakan sebuah keinginan yang dapat merugikan atau memberi rasa sakit kepada orang lain yang ditimbulkan oleh kekuatan supranatural. 


\begin{tabular}{|c|c|}
\hline Capture Visual 6 (Menit 17:05) & Audio 6 \\
\hline 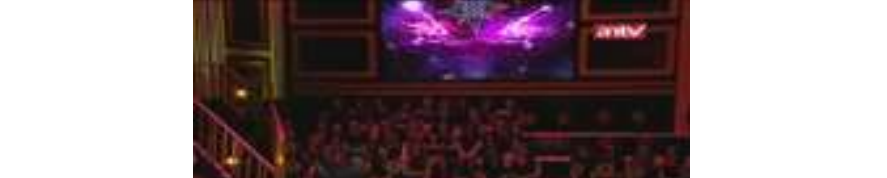 & $\begin{array}{l}\text { Uya: pocongnya masih menggangu apa gimana ? perlu } \\
\text { kita netralisir dulu apa gimana? } \\
\text { Arbi: energinya masih kerasa bolak-balik ini } \\
\text { dibelakang } \\
\text { Rudy: boleh minta garem kasar? }\end{array}$ \\
\hline $\begin{array}{l}\text { Denotasi: seorang pria berpakaian serba hitam berdiri menghadap beberapa } \\
\text { wanita berpakaian hitam dengan penutup wajah bagian mata yang duduk } \\
\text { dengan tanda nomor dihadapan mereka. Seorang wanita paling depan yang } \\
\text { duduk sendiri dibelakang meja menghadap kearah pria tersebut. Terdapat } \\
\text { teks "Rudy mencoba menetralisir area studio dengan menggunakan media } \\
\text { garam" }\end{array}$ & $\begin{array}{l}\text { Denotasi: seorang pria menanyakan situasi saat ini. Pria } \\
\text { yang satunya menjelaskan situasi, sedangkan pria } \\
\text { lainnya meminta sesuatu. }\end{array}$ \\
\hline $\begin{array}{l}\text { Konotasi: Rudy berkeliling studio dan menaburkan garam ke beberapa area } \\
\text { studio untuk menetralisir aura makhluk gaib yang menyebabkan kandidat } \\
\text { wanita kerasukan. }\end{array}$ & $\begin{array}{l}\text { Konotasi: Energi makhluk gaib pocong masih terasa di } \\
\text { aera studio, Rudy meminta garam sebagai alat pengusir } \\
\text { aura gaib. }\end{array}$ \\
\hline
\end{tabular}

Analisis komodifikasi pada sampel dua dapat dijelaskan bahwa sebagai program reality show pencarian jodoh, Garis Tangan sudah berlebihan dalam memasukkan unsur mistis pada proses pengenalan yang dilakukan untuk kandidat wanita bernama Anggi. Fokus pada episode ini justru mengarah pada kejadian aneh yang terjadi di dalam studio. Skenario yang disajikan adalah kericuhan para kandidat wanita karena beberapa orang diantara mereka terkena serangan oleh makhluk gaib. Hal ini dapat dilihat dari analisis visual 1 dimana seorang kandidat wanita melakukan pose seperti pocong. Uya Kuya sebagai host menambah suasana mistis semakin mencekam dengan mengatakan bahwa ia mencium bau sangit yang menandakan kedatangan makhluk gaib (analisis visul 3). Apa yang disajikan oleh Garis Tangan pada episode ini bukan lagi masalah perjodohan. Dari segmen yang berdurasi 20.22 menit ini, tidak ada satupun usaha baik itu dari host maupun kedua expertise untuk melakukan proses pengenalan yang baik pada Anggi dan dua orang kandidat pria yang tertarik padanya.

\section{PEMBAHASAN}

Berdasarkan hasil analisis pada sampel pertama, disimpulkan bahwa denotasi yang ditampilkan adalah orang-orang yang terlibat dalam usaha perjodohan antara pria dan wanita serta tindakan-tindakan tertentu yang digunakan untuk usaha porjodohan tersebut. Orang-orang yang terlibat adalah host yaitu Uya Kuya dan dua orang expertise yaitu Arbi dan Rudy. Tindakan yang mereka lakukan dalam usaha menjodohkan antara kandidat pria dan wanita diantaranya adalah membaca energi dalam tubuh kedua kandidat, melihat masa lalu kandidat dengan membaca garis tangan, melakukan relaksasi dengan perantara air, serta menunjukkan gambar makhluk halus yang menghalangi jodoh salah satu kandidat.

Mengenai mitos, pada sampel pertama dapat disimpulkan bahwa terdapat keyakinan-keyakinan yang disampaikan melalui program ini. Pertama, keyakinan bahwa seorang hypnoterapi dapat merasakan energi dalam tubuh seseorang dan dapat mengontrol energi tersebut melalui perantara seperti air. Kedua, kepercayaan pada kekuatan spiritual yang mampu membuat hal yang sulit menjadi lebih mudah, seperti penggunaan susuk dan mengirim kutukan atau santet. Ketiga, kepercayaan mengenai seorang indigo yang memiliki kemampuan khusus untuk membaca masa lalu dan masa depan seseorang melalui garis tangan, serta merasakan dan melihat makluk tak kasat mata (gaib). Keempat, keyakinan adanya makluk gaib yang dapat berinteraksi dengan manusia bahkan memberikan pengalaman buruk.

Pada sampel kedua, denotasi yang ditampilkan adalah tindakan-tindakan yang dilakukan oleh orang-orang yang terlibat dalam proses perjodohan. Tindakantindakan tersebut justru diluar konteks perjodohan pada umumnya, tindakan yang ditampilkan seperti: seorang kandidat wanita yang tiba-tiba melakukan pose melipat lengan didepan dada, Uya Kuya yang tiba-tiba menutup mulutnya karna mencium bau sangit, serta Rudy yang melemparkan garam disekitar studio.

Mitos yang ditampilkan pada sampel kedua adalah kepercayaan mengenai adanya makluk gaib yang dapat merasuki tubuh manusia. Makhluk gaib akan menunjukkan tanda apabila ia datang. Salah satunya 
adalah tanda bau sangit yang menandakan kedatangan sosok gaib pocong. Selain itu untuk mengusir makluk gaib, dapat dilakukan dengan melempar garam. Garam dianggap merupakan alat paling baik yang mampu mengidentifikasi beraneka ragam tipe dari energi baik itu positif maupun negatif.

Menurut Sobur (2016:70) denotasi biasanya dimengerti sebagai makna harfiah, makna yang sesungguhnya bahkan kadang kala juga diracunkan dengan referensi atau acuan." Maka makna denotasi yang terdapat pada keseluruhan sampel penelitian ini merupakan makna yang terlihat langsung dan belum dikaitkan dengan suatu apapun, artinya visualisasi langsung yang terlihat di dalam tayangan program reality show pencarian jodoh Garis Tangan di ANTV. Denotasi yang digambarkan dalam program tersebut adalah orang-orang yang terlibat dalam usaha perjodohan antara kandidat pria dan kandidat wanita serta tindakan-tindakan yang dilakukan dalam usaha perjodohan tersebut.

Selanjutnya, konotasi yang memiliki sifat subjektif, dimana terdapat pergeseran dari makna umum (denotasi) karena ada penambahan rasa dan nilai tertentu (Sobur, 2013:264), Maka makna konotasi pada program reality show pencarian jodoh Garis Tangan di ANTV disimpulkan bahwa terdapat makna di balik suatu penggambaran yang ada pada tiap-tiap scene dimana terdapat ritual-ritual yang dilakukan oleh host yaitu Uya kuya dan kedua expertise yaitu Arbi dan Rudy dalam usaha mereka untuk menjodohkan kandidat pria dan wanita. Ritual yang dilakukan adalah seperti relaksasi menggunakan perantara air, pembacaan masa lalu melalui garis tangan, penggambaran makhluk gaib, hingga pelemparan garam untuk netralisasi energi.

Sobur mengatakan mitos adalah bagaimana kebudayaan menjelaskan atau memahami beberapa aspek tentang relitas atau gejala alam, mitos merupakan produk kelas sosial yang mudah dimiliki suatu dominasi (2016:128).

Dari hasil analisis pada program reality show pencarian jodoh Garis Tangan di ANTV, dapat disimpulkan bahwa mitos yang ditampilkan adalah kepercayaan-kepercayaan mengenai adanya makhluk gaib. Kepercayaan yang ditampilkan seperti kemampuan seorang hypnoterapis yang dapat merasakan energi dan melakukan relaksasi, seorang indigo yang dapat melihat dan merasakan adanya makhluk gaib, kepercayaan pemakaian susuk untuk memikat lawan jenis, adanya arwah atau roh yang dapat merasuki tubuh manusia, pengusiran makhluk gaib dengan metode pelemparan garam, dan keyakinan terhadap orang pintar (dukun) yang dapat mengirimkan kutukan kepada orang lain.

\subsection{Analisis Komodifikasi Reality Show Pencari- an Jodoh Garis Tangan di ANTV}

Masyarakat membutuhkan hiburan mistis untuk menjawab rasa ingin tahu mereka terhadap misteri fisika (mistis). Karena, bagi mereka, itu merupakan sebuah petualangan batin. Hal semacam inilah yang mendorong manusia untuk menyukai tayangantayangan mistis.

ANTV memanfaatkan hal itu sebagai sebuah komoditas, dimana mereka membungkus pesan mistis dalam program reality show pencarian jodoh Garis Tangan sesuai dengan selera pasar yang dapat menarik minat penonton dan menaikkan rating. Hal ini dapat dilihat dari rating penonton program Garis Tangan di ANTV yang memperoleh share tertinggi dengan angka 16.3 sejak penayangannya pada 11 Oktober 2019 (Kapanlagi.com). Dengan perolehan share yang tinggi tersebut tentunya membuktikan bahwa program "Garis Tangan" banyak ditonton oleh masyarakat, dan program dengan unsur mistis sudah menjadi komoditas yang mampu memberikan nilai tukar dalam hal ini perolehan share yang bagus.

Rating merupakan sesuatu yang sangat erat hubungannya dengan indutri televisi. Pihak televisi melakukan upaya apapun untuk bisa mendongkrak rating. Situasi seperti ini justru melahirkan program-program yang tidak mendidik.

Rating sangat dibutuhkan untuk mengukur seberapa banyak masyarakat yang menyaksikan program tersebut. Jumlah penonton yang besar menjadi tolak ukur berhasil atau tidaknya suatu program televisi. Karena semakin besar penonton yang menyaksikan acara tersebut, maka makin tinggi pula rating yang diperoleh dan semakin tinggi pula daya tarik bagi pemasang iklan di televisi.

Komodifikasi konten kerap menambahkan hal-hal sensasional yang menarik perhatian ke dalam pesannya, meskipun kadang diluar esensi siaran acara tersebut. Dalam hal ini ANTV membumbui program reality show pencarian jodoh dengan unsur mistis, dimana mereka menggunakan dua orang expertise yang merupakan seorang hypnoterapis dan seorang indigo untuk melihat dan membongkar masalalu para kandidat. Masalalu mereka itulah yang nantinya akan 
digunakan sebagai kriteria kecocokan antara kandidat pria dan kandidat wanita.

Komodifikasi isi terjadi ketika pesan atau informasi bisa menyenangkan dan menghibur khalayak, dalam tayangan ini tentunya mistis yang sudah dijadikan 'gimmick' untuk menghibur khalayak, dengan bantuan host yaitu Uya Kuya, skenario, sound effect yang digunakan, serta teknik pengambilan gambar yang dipakai. Mistis yang disajikan oleh ANTV dalam program Garis Tangan sudah dipertontonkan sebagai tontonan yang wajar atau lumrah, bahkan diproduksi secara bebas sebagai bentuk komoditas yang memiliki nilai tukar di masyarakat.

Terkait dengan pandangan ideologi menurut Zoest, peneliti menilai bahwa ideologi yang dibawa oleh ANTV adalah ideologi kapitalisme yang berasal dari pemikiran Karl Marx. Ideologi menurut Marx tidak berbicara mengenai kebenaran, tidak berbicara mengenai kenyataan empirik, akan tetapi ideologi berbicara mengenai kemanfaatan, kepentingan, kemauan dan pamrih (Sobur, 2013: 212). Hal ini dibuktikan dengan adanya program Garis Tangan di ANTV yang dikemas sebagai salah satu program hiburan dengan format reality show yang menyajikan berbagai skenario dengan memasukkan unsur mistis, sebagai komoditas yang memiliki manfaat untuk dipertukarkan di pasar dan mendapatkan keuntungan sebanyak-banyaknya.

\section{KESIMPULAN}

Berdasarkan hasil analisis melalui semiotika model Roland Barthes terhadap program reality show pencarian jodoh Garis Tangan di ANTV episode "Bersetubuh Dengan Begu Ganjang!" dan "Dinikahi Batu Nisan!" ditemukan tanda-tanda beserta makna yang mengidentifikasikan telah terjadi praktik komodifikasi mistis dalam konten program.

Proses yang terjadi dalam komodifikasi mistis diawali dengan memasukkan dua orang expertise yaitu seorang hypnoterapis dan seorang indigo untuk melihat dan membongkar masalalu para kandidat. Kemudian masalalu mereka itulah yang nantinya digunakan sebagai kriteria kecocokan antara kandidat pria dan kandidat wanita. Dari program tersebut dihasilkan kepercayaan-kepercayaan akan hal mistis yang telah dikomodifikasikan.

Kepercayaan yang ditampilkan seperti kemampuan seorang hypnoterapis yang dapat merasakan energi dan melakukan relaksasi, seorang indigo yang dapat melihat dan merasakan adanya makhluk gaib, kepercayaan pemakaian susuk untuk memikat lawan jenis, adanya arwah atau roh yang dapat merasuki tubuh manusia, pengusiran makhluk gaib dengan metode pelemparan garam, dan keyakinan terhadap orang pintar (dukun) yang dapat mengirimkan kutukan kepada orang lain.

Rating menjadi salah satu alasan ANTV melakukan komodifikasi konten terhadap program pencarian jodoh "Garis Tangan". Perolehan rating sebanyak 16.3 menjadi tolak ukur pengiklan untuk memasarkan produknya selama jeda program tersebut.

Berdasarkan hasil penelitian, dikemukakan beberapa saran:

1. Kepada televisi sebagai media massa yang punya pengaruh besar, sebaiknya membuat konten yang mendidik dan tidak menyesatkan. Ketika mistis dimasukkan ke dalam konten program, itu akan punya pengaruh kepada keyakinan masyarakat. Dimana itu justru akan memperkuat kepercayaan masyarakat akan adanya makhluk gaib dan halhal supranatural.

2. Kepada masyarakat diharapkan agar tidak mudah terjebak dalam kepercayaan-kepercayaan yang ditampilkan dalam sebuah program televisi

\section{DAFTAR PUSTAKA}

Abadi, S. Hidayat. 2019. Komodifikasi Agama dalam Iklan Televisi Ramadhan (Analisis Semiotika terhadap Iklan TV Ramayana Edisi Ramadhan 2017). Surabaya: Universitas Islam Negeri Sunan Ampel.

Badjuri, Adi. 2010. Jurnalistik Televisi. Yogyakarta: Graha Ilmu.

Bonardo, Marulitua A. 2015. Komodifikasi Disabilitas sebagai Tayangan Populer di Televisi. Semarang: Universitas Diponegoro

Bungin, Burhan. 2007. Penelitian Kualitatif: Котиnikasi, Ekonomi, Kebijakan Publik, danIlmu Sosial Lainnya. Jakarta: Kencana.

Chrysilla, Agnes., \& Kurniasari, Nani. 2018. Komodifikasi Kemarahan dalam Tayangan Supertrap Trans TV. Jurnal Bisnis dan Kominikasi Kalbisocio Volume 5 Nol.

Eriyanto. 2012. Analisis Wacana Pengantar Analisis Teks Media. Yogyakarta: PT. LkiS Printing Cemerlang.

Halim, Syaiful. 2013. Postkomodifiaksi Media dan Cultural Studies. Bandung: Penerbit Matahati. 
Harahap, Machyudin Agung. 2013. Kapitalisme Media. Yogyakarta: Aura Pustaka.

Hasan, Sumaerah. 2018. Komodifikasi Kemiskinan dalam Acara Reality Show Mikrofon Pelunas Utang di Indosiar. Universitas Hasanuddin.

http://www.kpi.go.id/index.php/id/umum/38-dalamnegeri/34667-siaran-pers-kpi-pusat-keluarkanedaran-tentang-pedoman-dan-batasanpenayangan-program-siaran-mistik-horor-dansupranatural?detail $3=5212$

https://www.google.com/amp/s/m.kapanlagi.com/am $\mathrm{p} /$ showbiz/selebriti/garis-tangan-antv-dibilangsettingan-begini-taggapan-para-host0c345f.html

https://www.google.com/amp/s/m.solopos.com/realit y-show-baru-uya-kuya-acara-perjodohandibalut-mistis-1026733/amp

https://www.google.com/amp/s/www.viva.co.id/amp/ showbiz/film/1184988-tayang-di-antv-garistangan-kolaborasi-antara-cari-jodoh-dan-mistis

https://youtu.be/Z86aOdu3RoA

Ibrahim, Idi Subandy \& Akhmad, Bachruddin Ali. 2014. Komunikasi \& Komodifikasi: Mengkaji Media dan Budaya dalam Dinamika Globalisasi. Jakarta: Yayasan OBOR.

Ishadi, SK. 2014. Media dan Kekuasaan. Jakarta: PT Kompas Media Nusantara.

Kriyantono, Rachmat. 2010. Teknik Riset Komunikasi: Disertai Contoh Praktis Riset Media, Public Relations, Advertising, Komunikasi, Organisasi, Komunikasi Pemasaran. Jakarta: Prenada Media Group.

Milkiyah, Farah. 2017. Strategi Komodifikasi Tim Program "Jejak Leluhur" Episode Susuk di ANTV. Jakarta: Universitas Bakrie.

Morgan, W Kenneth. 1985. Islam Jalan Lurus, terj. Abu Salamah dan Chaidir Anwar. Jakarta: Pustaka Jaya

Morissan. 2009. Manejemen Media Penyiaran: Strategi Mengelola Radio dan Televisi. Jakarta: Penerbit Kencana Prenada Media Group.

Mosco, Vincent. 2009. The Political Economy of Communication: Second Edition. London: Sage.
Nikmah, Aulia. 2018. Komodifikasi Hijab dalam Program Acara Televisi (Analisis Semiotika Program Acara Televisi Dua Hijab Trans7). Semarang: Universitas Islam Negeri Walisongo.

Perdana, Dionni Ditya. 2017. Komudifikasi Dalam Tayangan Televisi (Kajian Terhadap Program Indonesia Idol 2014). Jurnal Professional FIS UNIVED Vol 4 No 1.

Prastowo, Andi. 2011. Memahami Metode-Metode Penelitian. Yogyakarta: Ar-Ruzz Media.

Robin, Patricia. 2015. Mitologi dan Ideologi Addry Danuatmadja Selaku Host !nsert dengan Bahasan Pemakaman San Diego Hills diInverstigasi Trans TV. Jurnal Semiotika Volume 9 Nomor 1.

Rustandi, Ridwan. 2018. Analisis Wacana Kritis Komodifikasi Dai dalam Program Televisi. Communicatus: Jurnal Ilmu Komunikasi, Vol. 2 No. 2, 197-222.

Salim, Agus., \& Syas, Mulharnetti. 2019. Komodifikasi Pertukaran Peran Gender pada Sinetron Dunia Terbalik di RCTI. Jurnal Ilmu dan Budaya Volume 41 No 64.

Shihab, M. Quraish. 2000. Yang Tersembunyi: Jin, Iblis, Setan \& Malaikat dalam Al-Qur'an-AsSunnah serta wacana pemikiran ulama masa lalu dan masa kini. Jakarta: Lentera Hati

Sobur, A. 2016. Semiotika Komunikasi. Bandung: Remaja Rosdakarya.

Sugiyono. 2013. Metode Penelitian Kuantitatif Kualitatif dan R\&D. Bandung: Alfabeta.

Susanti, Nesa. Representasi Kemiskinan pada Tayangan Reality Show Orang Pinggiran Episode Bakti Suci Andika.Jom FISIP Volume 4 No 2.

Thadi, Robeet. 2020. Analisis Kritis Sinetron Religi: Antara Dakwah dan Kepentingan Komersial. Jurnal Dawuh Vol 1 Nomor 1.

Vivian, John. 2008. Teori Komunikasi Massa, Edisi Kedelapan. Jakarta: Penerbit Kencana.

Yunus, Syarifudin. 2010. Jurnalistik Terapan. Jakarta: Ghalia Indonesia. 